\title{
FAKTOR-FAKTOR YANG MEMPENGARUHI KEJADIAN PNEUMONIA PADA BALITA DI RUMAH SAKIT IBU ANAK PERMATA HATI KABUPATEN KLUNGKUNG TAHUN 2015-2017
}

\author{
Dea Eka Manuwati Ramandey*, Ni Made Dian Kurniasari, Desak Nyoman Widyanthini \\ Program Studi Kesehatan Masyarakat Fakultas Kedokteran Universitas Udayana \\ *Email: dea_ramandey@yahoo.com
}

\begin{abstract}
ABSTRAK
Pneumonia merupakan proses infeksi akut yang mengenai jaringan paru-paru (alveoli). Pneumonia pada balita di Indonesia masih merupakan masalah kesehatan utama, dilihat dari tingginya angka kepadatan penduduk setiap tahunnya. Salah satu upaya untuk menurunkannya adalah dengan mengetahui faktor faktor yang menyebabkan terjadinya pneumonia. Penelitian ini bertujuan untuk mengetahui faktor-faktor yang mempengaruhi kejadian pneumonia pada balita di RSIA Permata Hati Kabupaten Klungkung. Jenis penelitian ini menggunakan pendekatan kuantitatif analitik dengan rancangan kasus kontrol (case control study). Sampel dari penelitian ini yaitu sebanyak 80 diantaranya 40 ibu yang memiliki balita tidak pneumonia sebagai kelompok kontrol dan 40 ibu yang memiliki balita pneumonia sebagai kelompok kasus. Pengambilan sampel pada kasus dengan simple random sampling dan pada kontrol dengan purposive sampling. Dengan wawancara menggunakan kuesioner. Analisis data mencakup analisis univariat dan bivariat. Hasil penelitian menunjukkan faktor determinan yang mempengaruhi pada kejadian pneumonia pada balita adalah faktor jenis kelamin $(\mathrm{OR}=$ 3,095 95\% CI=1,134-8,530; $\mathrm{p}=0,013$ ), berat badan lahir ( $\mathrm{OR}=12,666$ 95\% $\mathrm{CI}=2,540-119,627 ; \mathrm{p}=0,0002)$, pemberian vitamin A (OR=25,705 95\% CI=5,610-238,625; $\mathrm{p=0,0001),ASI}$ ekslusif (OR=16,333 95\% CI=4,628-64,082 ; $\mathrm{p}=$ 0,0001), paparan asap rokok (OR=3,44 95\% CI=1,191-10,294; $\mathrm{p}=0,010)$. Simpulan dari penelitian ini adalah faktor yang mempengaruhi determinan pneumonia pada balita adalah faktor anak dan lingkungannya.
\end{abstract}

Kata kunci: Pneumonia, Balita, Faktor-faktor

\section{ABSTRACT}

Pneumonia is an acute infection process that affects the lung tissue (alveoli). Pneumonia in toddlers in Indonesia is still a major health problem, seen from the high population density each year. One effort to reduce it is by knowing the factors that cause pneumonia. This study aims to determine the factors that influence the incidence of pneumonia in infants at RSIA Permata Hati, Klungkung Regency. This type of research uses a quantitative analytical approach with a case control study. The samples of this study were 80 of them 40 mothers who had no pneumonia as a control group and 40 mothers who had pneumonia as a case group. Sampling in cases with simple random sampling and in controls with purposive sampling. With interviews using a questionnaire. Data analysis includes univariate and bivariate analysis. The results showed that the determinant factors affecting the incidence of pneumonia in infants were gender $(\mathrm{OR}=3,09595 \% \mathrm{CI}=1,134-8,530 ; \mathrm{p}=0.013)$, birth weight $(\mathrm{OR}=$ $12,66695 \% \mathrm{CI}=2,540-119,627 ; \mathrm{p}=0,0002)$, giving vitamin $\mathrm{A}(\mathrm{OR}=25,70595 \% \mathrm{CI}=5,610-238,625 ; \mathrm{p}=0,0001)$, exclusive breastfeeding $(\mathrm{OR}=16,33395 \% \mathrm{CI}=4,628-64,082 ; \mathrm{p}=0,0001)$, smoke exposure cigarettes $(\mathrm{OR}=3.4495 \%$ $\mathrm{CI}=1,191-10,294 ; \mathrm{p}=0.010)$. The conclusions of this study are the factors that influence the determinants of pneumonia in toddlers are the factors of children and their environment.

Keywords: Pneumonia, toddler, the factors

\section{PENDAHULUAN}

Menurut WHO angka kematian balita pada tahun 2013 masih tinggi mencapai 6,3 juta jiwa. Kematian balita tertinggi terjadi di negara berkembang sebanyak $92 \%$ atau 29.000 balita/hari (Rahman dkk, 2014). Kematian balita sebagian besar disebabkan oleh penyakit menular seperti pneumonia $(15 \%)$, diare $(9 \%)$, dan malaria $(7 \%)$ (WHO, 2013). WHO memperkirakan pada tahun 2013, ada 935.000 balita meninggal karena pneumonia (WHO, 2014).

$$
\text { World Health Organization (WHO) }
$$

(2006) menyatakan bahwa pneumonia adalah suatu penyakit yang terbentuk dari infeksi akut dari daerah saluran pernafasan bagian bawah yang secara spesifik mempengaruhi paru-paru. Pneumonia juga didefinisikan sebagai salah satu penyakit infeksi saluran pernafasan akut yang mengenai jaringan 
alveolus pada paru-paru (Depkes RI, 2009). Kematian balita karena pneumonia sebagian besar diakibatkan oleh pneumonia berat berkisar antara 7\%-13\%. Setiap tahun diperkirakan lebih dari 2 juta balita meninggal karena pneumonia (1 balita /15 detik) dari 9 juta total kematian balita di seluruh dunia. Tidak banyak perhatian terhadap penyakit ini, sehingga pneumonia disebut juga pembunuh balita yang terlupakan atau The Forgotten Killer of Children (WHO, 2010).

Provinsi bali merupakan provinsi nomor dua dengan kejadian pneumonia tertinggi di Indonesia pada tahun 2007 sebesar 12,9\% (Kemenkes RI, 2010). Pada saat ini kasus pneumonia pada balita tahun 2015 sebesar 5,32\%. Sedangkan pada tingkat kabupaten/kota kasus pneumonia tertinggi adalah kabupaten klungkung yaitu 50,85\% (Profil Kesehatan Provinsi Bali, 2015). Rumah Sakit Ibu Anak Permata Hati merupakan rumah sakit di Kabupaten Klungkung dengan jumlah kasus pneuonia tertinggi. Data pada tahun 2015 menunjukan jumlah kasus pneumonia balita sebesar $8 \%$ dari 271 balita yang berkunjung di RSIA Permata Hati. Pada tahun 2016 menunjukan jumlah kasus pneumonia balita sebesar $28 \%$ dari 269 balita yang berkunjung di RSIA Permata Hati. Sedangkan pada tahun 2017 menunjukan jumlah kasus pneumonia balita sebesar 14,5\% kejadian pneumonia pada balita dari 269 balita yang berkunjung di RSIA Permata Hati (Data Rawat Inap RSIA Permata Hati, 2015, 2016, 2017).

Tingginya kejadian pneumonia ini dipengaruhi oleh beberapa faktor risiko diantaranya berhubungan dengan host,

environment dan agent, yang meliputi malnutrisi, BBLR (kurang dari 2500 gr saat lahir), ASI Eksklusif (selama 6 bulan pertama kehidupan), tidak melakukan imunisasi campak (dalam waktu 12 bulan pertama kehidupan), polusi udara didalam rumah dan kepadatan rumah (WHO, 2008). Kemungkinan faktor risiko lain adalah kekurangan zinc, pengalaman ibu sebagai pengasuh, penyakit penyerta misalnya diare, penyakit jantung asma, pendidikan ibu, kelembaban udara, kekurangan vitamin A (Rudan et,al, 2008)

Hasil penelitian Setiawan R, dkk (2010), menyimpulkan bahwa balita yang mempunyai status gizi buruk berisiko terkena pneumonia sebesar 27 kali dengan pengukuran berat badan menurut umur $(\mathrm{BB} / \mathrm{U})$ dengan melihat KMS yang dimiliki balita. Status gizi dan infeksi saling berinteraksi, karena infeksi dapat mengakibatkan status gizi kurang dengan berbagai mekanisme dan sebaliknya status gizi juga dapat menyebabkan infeksi (Adhi, 2008, dalam Adriani, 2014). Berdasarkan penelitian Andri Widayat (2014) yang dilakukan di wilayah kerja Puskesmas Mojogedang II menyimpulkan bahwa adanya hubungan antara pemberian ASI Eksklusif, penggunaan kayu bakar dan keberadaan perokok dengan kejadian pneumonia.

Berdasarkan latar belakang di atas peneliti bermaksud untuk menganalisis "Faktor-Faktor Yang Mempengaruhi Kejadian Pneumonia Pada Balita Di Rumah Sakit Ibu Anak Permata Hati Kabupaten Klungkung Tahun 2015-2017".

\section{METODE}


Penelitian ini merupakan penelitian dengan rancangan case control melalui pendekatan metode kuantitatif. Rancangan case control merupakan sebuah penelitian analitik yang menyangkut bagaimana faktor risiko dipelajari dengan menggunakan pendekatan retrospective dengan membandingkan kelompok kasus dan kelompok kontrol berdasarkan status paparannya. Adapun Penggunaan desain penelitian ini dimaksudkan agar melihat hubungan antara efek (penyakit atau kondisi kesehatan) tertentu dengan faktor risiko tertentu. Dalam Penelitian ini memakai desain case control dengan membandingkan faktor risiko balita pneumonia dan balita yang tidak pneumonia di RSIA Permata Hati Kabupaten Klungkung tahun 2015-2017.

\section{HASIL}

\section{a. Karakteristik Responden (Ibu)}

Penelitian ini dilakukan terhadap 80 orang ibu yang memiliki balita. Kelompok kasus adalah $40 \mathrm{ibu}$ yang memiliki balita yang menderita pneumonia di RSIA Permata Hati Kabupaten Klungkung tahun 2015-2017, sedangkan kelompok kontrol adalah balita yang berasal dari daerah yang sama dengan kasus. pendidikan ibu baik pada kelompok kasus maupun kelompok kontrol pendidikan tertinggi ibu adalah SMA, yaitu $47,50 \%$ pada kelompok kasus dan 57,50\% pada kelompok kontrol. Pekerjaan ibu yang paling banyak baik pada kasus maupun kontrol adalah swasta, 42,50\% pada kelompok kasus dan $45,00 \%$ pada kelompok kontrol.

\section{b. Karakteristik Balita}

Pada balita yang mengalami pneumonia, proporsi balita berjenis kelamin laki-laki lebih banyak (65,00\%) dibandingkan dengan balita yang tidak pneumonia (37,50\%). Pada balita yang mengalami pneumonia, proporsi balita yang memiliki umur $\leq 14$ bulan adalah $(62,50 \%)$, persentase tersebut jauh lebih banyak dibandingkan dengan balita yang tidak pneumonia $(42,50 \%)$. Balita dengan berat badan lahir $\leq 2,5 \mathrm{~kg}$ pada balita pneumonia memiliki proporsi lebih banyak $(40,00 \%)$ dibandingkan dengan balita yang tidak pneumonia (5,00\%). Pada balita yang mengalami pneumonia, proporsi balita yang tidak mendapatkan vitamin A adalah (57,50\%), persentase tersebut jauh lebih banyak dibandingkan pada balita yang tidak pneumonia (12.50\%). Dilihat dari pemberian Asi eksklusif pada balita yang mengalami pneumonia, proporsi balita yang tidak mendapatkan ASI ekslusif lebih banyak (70\%) dibandingkan pada balita yang tidak pneumonia (12.50\%).

\section{c. Karakteristik Lingkungan}

Pada balita yang mengalami pneumonia, proporsi balita yang terpapar asap rokok adalah (77,50\%) jauh lebih banyak dibandingkan dengan balita yang tidak pneumonia (50,00\%). Kelompok balita yang mengalami pneumonia, proporsi balita yang bertempat tinggal di hunian padat lebih banyak (15,00\%) dibandingkan balita yang tidak pneumonia (12,00\%). Pada balita yang menderita pneumonia, proporsi balita yang tempat tinggalnya menggunakan obat nyamuk bakar lebih banyak $(35,00 \%)$ dibandingkan dengan balita yang tidak pneumonia $(22,50 \%)$.

d. Analisis Bivariat Faktor-faktor yang Mempengaruhi Kejadian Pneumonia 
pada Balita di Rumah Sakit Ibu AnaK

Permata Hati Kabupaten Klungkung 2015-2017

Dari analisis bivariat di atas variabel yang mempengaruhi kejadian pneumonia pada balita adalah jenis kelamin, berat badan lahir balita, pemeberian ASI eksklusif, pemberian vitamin $\mathrm{A}$, dan paparan asap rokok. Balita berjenis kelamin laki-laki memiliki odd 3 kali lebih besar untuk terkena pneumonia dibandingkan dengan balita perempuan $(\mathrm{OR}=3,095 ; 95 \% \mathrm{CI}=1,134-8,530)$. Balita dengan berat badan $<2,5 \mathrm{~kg}$ memiliki odd 12,6 kali lebih besar untuk terkena pneumonia dibandingkan dengan balita yang memiliki berat badan $\geq 2,5 \mathrm{~kg}$ (OR = $12,666 ; 95 \% \mathrm{CI}=2,540-119,627)$.

Berdasarkan status pemberian vitamin A, balita yang tidak mendapatkan vitamin A memiliki peluang untuk terkena pneumonia 25,7 kali lebih besar dibandingkan dengan balita yang mendapatkan vitamin A (OR $=25,705 ; 95 \%$ $\mathrm{CI}=5,610-238,625)$. Balita yang tidak diberikan ASI eksklusif memiliki odd 16,3 kali lebih besar untuk terkena pneumonia dibandingkan dengan balita yang mendapatkan ASI eksklusif $(\mathrm{OR}=16,333$; 95\% CI = 4,628-64,082). Berdasarkan status paparan asap rokok, balita yang terpapar asap rokok memiliki peluang 3,4 kali lebih besar untuk terkena pneumonia dibandingkan dengan balita yang tidak terpapar asap rokok $(\mathrm{OR}=3,444 ; 95 \% \mathrm{CI}=$ 1,191-10,294).

Variabel yang tidak berpengaruh secara signifikan jika dilihat dari nilai OR adalah umur, kepadatan hunian dan penggunaan obat nyamuk bakar. Balita yang memiliki umur $\leq 14$ bulan memiliki OR=2,254 yang artinya meningkatkan odd 2,2 kali untuk terkena pneumonia dibandingkan dengan balita yang memiliki umur $\geq 14$ bulan (OR = 2,254; 95\% CI =0,841-6,096), namun tidak bermakna secara statistik. Balita yang bertempat tinggal dihunian padat memiliki odd 1,2 kali lebih besar dibandingkan dengan balita yang tidak bertempat tinggal dihunian padat untuk terkena pneumonia, namun tidak bermakna secara statistik (OR $=1,235 ; 95 \%$ CI $=0,283-5,6201)$. Dari penggunaan obat nyamuk bakar balita yang memiliki tempat tinggal menggunakan obat nyamuk bakar memiliki peluang untuk terkena pneumonia 1,9 kali lebih besar dibandingkan dengan balita yang tempat tinggalnya tidak menggunakan obat nyamuk bakar, namun tidak bermakna secara statistik (OR $=1,854 ; 95 \% \mathrm{CI}=0,623$ $5,676)$.

\section{DISKUSI}

\section{Faktor Anak (host) Terhadap Kejadian Pneumonia pada Balita}

Faktor host yang mempengaruhi kejadian pneumonia pada balita adalah jenis kelamin, berat badan lahir, pemberian vitamin A dan pemberian ASI eksklusif.

Pada penelitian ini mendapatkan hasil bahwa, balita laki-laki memiliki odd 3 kali lebih besar untuk terkena pneumonia dibandingkan dengan balita perempuan. Penelitian sejenis dilakukan oleh Dian Rahayu (2012) di 4 Provinsi di Wilayah Indonesia Timur juga menyatakan bahwa balita laki-laki memiliki odd 1,45 kali lebih besar di banding balita perempuan untuk terkena pneumonia.

Selain jenis kelamin, adapun faktor lain yang mempengaruhi kejadian 
pneumonia pada balita adalah berat badan lahir. Balita yang memiliki berat badan lahir kurang dari 2,5 kg memiliki odd 1,2,6 kali lebih besar dibandingkan dengan balita yang memiliki berat badan lahir lebih dari 2,5 kg untuk terkena pneumonia. Penelitian ini sejalan dengan hasil penelitian Adri wijayat (2014) di Puskesmas Mojogedang II Kabupaten Karanganyar yang menunjukan bahwa balita yang memiliki berat badan lahir kurang dari 2,5 $\mathrm{kg}$ memiliki odd 3 kali lebih besar untuk terkena pneumonia dibandingkan dengan balita yang memiliki berat badan lebih dari $2,5 \mathrm{~kg}$.

Selain berat badan lahir, adapun faktor lain yang mempengaruhi kejadian pneumonia pada balita adalah pemberian vitamin A. Balita yang tidak mendapatkan vitamin A memiliki risiko 25,7 kali lebih besar untuk terkena pneumonia dibandingkan dengan balita yang mendapatkan vitamin A. Penelitian ini sejalan dengan penelitian Hatta (2000) di Kabupaten OKU Kalimantan Timur, yang menyatakan bahwa anak balita yang tidak mendapatkan vitamin A mempunyai risiko 2,495 kali besar untuk terkena pneumonia dibandingkan dengan balita yang pernah mendapatkan vitamin A.

Selain itu faktor host yang mempengaruhi terjadinya pneumonia pada balita adalah pemberian ASI eksklusif. Balita yang tidak mendapatkan ASI eksklusif memiliki odd 16 kali lebih besar untuk terkena pneumonia dibandingkan dengan balita yang mendapatkan ASI eksklusif. Penelitian ini sejalan dengan hasil penelitian Naim (2013) di Jawa Barat yang menyatakan bahwa anak usia 4 bulan - 24 bulan yang tidak mendapat ASI eksklusif memiliki odd 4,76 kali untuk terkena pneumonia dibanding anak umur 4 bulan-24 bulan yang diberi ASI eksklusif.

Faktor host yang tidak mempengaruhi terjadinya pneumonia pada balita adalah umur. Balita yang memiliki umur kurang dari 14 bulan memiliki risiko 2,2 kali lebih besar untuk terkena pneumonia, namun tidak bermakna secara statistik. Hasil penelitian ini sejalan dengan penelitian Rizka (2011) di Wilayah Kerja Puskesmas Paciran Lamongan yang menunjukan tidak ada hubungan secara statistik antara umur balita dengan kejadian pneumonia pada balita.

\section{Faktor Lingkungan Terhadap Kejadian Pneumonia pada Balita}

Faktor lingungan yang mempengaruhi terjadinya pneumonia pada balita adalah paparan terhadap asap rokok.

Penelitian ini menunjukan bahwa balita yang terpapar asap rokok memiliki odd 3,4 kali lebih besar untuk terkena pneumonia dibandingkan dengan balita yang tidak terpapar asap rokok. Hasil penelitian ini sejalan dengan hasil penelitian Tulus Aji Yuwono (2011) yang menyatakan bahwa kebiasaan anggota keluarga yang merokok berhubungan secara bermakna dengan kejadian pneumonia pada balita. Penelitian lain sejalan yaitu dilakukan oleh Adri wijayat (2014) di Puskesmas Mojogedang II Kabupaten Karanganyar menunjukan bahwa ada hubungan antara keberadaan perokok dengan kejadian pneumonia pada balita.

Faktor lingkungan yang tidak mempengaruhi terjadinya pneumonia pada balita adalah kepadatan hunian. 
Balita yang memiliki tempat tinggal hunian padan meningkatkan peluang 1,2 kali lebih besar untuk terkena pneumonia, namun tidak memiliki pengaruh secara bermakna dengan kejadian pneumonia pada balita. Penelitian ini sejalan dengan penelitian Embriyowati (2012) di Kecamatan Gombong Kabupaten Kebumen Jawa Tengah yang menyatakan bahwa tidak adanya hubungan antara kepadatan hunian dengan kejadian pneumonia pada balita.

Selain kepadatan hunian, faktor lingkungan yang tidak mempengaruhi kejadian pneumonia pada balita adalah penggunaan obat nyamuk bakar. Balita yang tempat tinggalnya menggunakan obat nyamuk bakar memiliki odd 1,8 kali lebih besar untuk terkena pneumonia dibandingkan dengan balita yang tempat tinggalnya tidak menggunakan obat nyamuk bakar, namun tidak berpengaruh secara bermakna dalam. Hasil penelitian ini sejalan dengan penelitian yang dilakukan oleh Lenni Marlina (2014) di Puskesmas Panyabunganjae Kabupaten Mandagiling Natal yang menyatakan bahwa tidak ada hubungan bermakna antara penggunaan obat nyamuk bakar dengan kejadian pneumonia.

\section{SIMPULAN}

Pada penelitian ini variabel yang berpengaruh bermakna terhadap kejadian pneumonia pada balita di Kabupaten Klungkung adalah jenis kelamin, berat badan lahir, pemberian vitamin $\mathrm{A}$, pemberian ASI eksklusif, dan paparan terhadap asap rokok. Jenis memiliki peluang 3 kali lebih besar untuk terkena pneumonia. Berat badan lahir kurang dari
2,5 kg meningkatkan resiko 12 kali terhadap kejadian pneumonia. Balita yang tidak mendapatkan vitamin A memiliki peluang 25 kali lebih besar untuk terkena pneumonia. Balita yang tidak mendapatkan ASI eksklusif meningkatkan resiko 16 kali lebih besar untuk terkena pneumonia. Paparan asap rokok memberikan risiko 3 kali lebih besar terhadap kejadian pneumonia pada balita. Variabel yang tidak berpengaruh bermakna terhadap kejadian pneumonia adalah umur, kepadatan hunian dan penggunaan obat nyamuk bakar.

\section{UCAPAN TERIMA KASIH}

Ucapan terimakasih disampaikan kepada semua pihak yang telah membantu kelancaran penelitian ini, baik berupa dukungan teknis, motivasi, dan support dalam menyelesaikan penelitian ini.

\section{DAFTAR PUSTAKA}

Depkes RI. (2009). Panduan Suplementasi Vitamin A.

Dian Rahayu. (2012). Analisis Faktor Resiko Pneumonia Pada Balita di 4 Provinsi Di Wilayah Indonesia Timur. [Skripsi]. Universitas Indonesia

Embriyowati. (2012). Faktor Yang Berhubungan Dengan Kejadian ISPA di Kecamatan Gombong Kabupaten Kebumen Jawa Tengah. [Skripsi]. Universitas Indonesia.

Hatta. (2000). Faktor-Faktor Yang Mempengaruhi Kejadian Pneumonia Pada Balita di Kabupaten Oku Kalimantan Timur. [Artikel Ilmiah]. Universitas Diponegoro

Kemenkes RI, Subdit Infeksi Saluran Pernafasan Akut Tahun 2010 
Lenni Marlina. (2014). Faktor-Faktor Yang Mempengaruhi Kejadian Ifeksi Saluran Pernafasan Akut (ISPA) Pada Anak Balita di Puskesmas Panyabunganjae Kabupaten Mandagiling Natal. Universitas Sumatra Utara Medan.

Naim. (2013) Determinan Faktor Yang Mempengaruhi Kejadian Pneymonia Pada Balita di Jawa Barat. [Artikel Ilmiah]. Universitas Brawijaya.

Widayat A. 2014. Faktor-Faktor Yang Berhubungan Dengan Kejadian Pneumonia Di Wilayah Kerja Puskesmas Mojogedeng II Kabupaten Karanganyar. [Skripsi]. Surakarta: Universitas Muhammmadiyah Surakarta.

Yuwono, Aji T. Faktor-faktor lingkungan fisik rumah yang berhubungan dengan kejadian pneumonia pada anak balita di wilayah kerja puskesmas Kawunganten Kabupaten Cilacap. Tesis. Semarang. Program Pasca Sarjana Universitas Diponegoro Semarang. 